\title{
Characterization of Biobased Alginate/Glycerol/ Sunflower Oil as Biodegradable Packaging
}

\author{
Maula Yasinta Dewi and Amir Husni* \\ Department of Fisheries, Faculty of Agriculture, Universitas Gadjah Mada, Yogyakarta 55281, \\ Indonesia
}

\begin{abstract}
The most used packaging material was plastic, but can cause environmental problems because it was not easily degraded. Therefore, it was necessary to look for alternative packaging materials that are easily biodegraded including edible film. The main raw materials for edible films were alginates and plasticizers including glycerol and sunflower oil. The objective of this study was to determine the characteristics of edible film composed of alginate, glycerol and sunflower oil. The study was carried out through the manufacture of edible films composed of various alginates concentrations (2, 3, 4, 5 and $6 \%), 10 \%$ glycerol and $0.01 \%$ sunflower oil. The characteristics tested included thickness, tensile strength, elongation, solubility, and rate of water vapor transmission. The results showed that all treatments met the edible film standard of the Japanese Industrial Standard. The various alginate concentrations used did not significantly influence the water vapor transmission rate and tensile strength but significantly affected the elongation, solubility and thickness of the edible film.
\end{abstract}

\section{Introduction}

The rapid development of food products has the effect of increasing food packaging production. Synthesis plastic is the most popular ingredient as food packaging material in the world. Plastics are non-degradable polymers, which are resistant to degradation so other alternatives are needed to reduce plastic waste. One effort that can be done is to reduce the use of plastic and replace it using biodegradable materials. Edible films can be used as biodegradable packaging.

The use of alginate as a raw material for the manufacture of edible films has a good ability to protect the product against oxygen, carbon dioxide, oil, and improve the unity of the product structure [1-2]. The disadvantages are the same as polysaccharides and other hydrocolloids, alginate has a hydrophilic nature. If alginate is used as raw material for edible film, it will produce a neat film, high moisture permeability, and less flexible, so that efforts are needed to fix it, one of which is to add elastic plasticizer [3].

Plasticizers that can be used in addition to glycerol are groups of lipids and their derivatives, for example phospholipids, fatty acids, and surfactants [4]. Sunflower oil can act as a plasticizer. Some lipids such as vegetable oil, lecithin, fatty acids and wax are added to the film as plasticizers. The use of lipids for edible film formulations is influenced by the

* Corresponding author: a-husni@ugm.ac.id 
concentration to be used. Research conducted by Utomo and Farid [5] regarding the effect of lipid and antioxidant incorporation on the mechanical properties and permeability of edible film of corn starch showed that the addition of $0.15 \%$ sunflower oil concentration gave the best treatment. So that research is needed on the combination of the treatment of various concentrations of sunflower oil which gives the best results on the characteristics of alginatebased edible films. This study aims to determine the characteristics of composite alginate, glycerol and sunflower oil with various concentrations.

\section{Materials and methods}

\subsection{Materials}

The materials used were sodium alginate (Multi Kimia Raya Semarang), distilled water, sunflower oil, glycerol and $\mathrm{CaCl} 2$ from Progo Mulyo Yogyakarta and PA ethanol. The equipment to be used in the manufacture of edible films were glass plates, hot plate stirrers (AREC T VELP SCIENTIFICA F20500051), glass cups, ovens (EYELA WFO-601 SD), analytical scales (OHAUS NVT10001/3), spatulas, measuring cups. Characteristics of edible film test equipment were micrometer, Erlenmeyer and Universal Testing Machine instrument.

\subsection{Preparation of edible film}

The research was conducted by making alginate edible film which refers to the method of Anward et al. [6] with modification, namely dissolving sodium alginate in distilled water with variations in the concentration of alginate $2 \% \mathrm{w} / \mathrm{w}, 3 \% \mathrm{w} / \mathrm{w}, 4 \% \mathrm{w} / \mathrm{w}, 5 \% \mathrm{w} / \mathrm{w}$ and $6 \% \mathrm{w} / \mathrm{w}$ based on the volume of $100 \mathrm{ml}$ solution . then the solution is stirred until homogeneous at room temperature. Next, $10 \%$ glycerol is added to the alginate solution and stirred until homogeneous. $0.01 \%$ sunflower oil which has been dissolved in pure ethanol is then added to the alginate solution and stirred again until homogeneous. The alginate solution is printed on a glass plate measuring $15 \mathrm{~cm} \times 20 \mathrm{~cm}$ with a thickness of $0.3 \mathrm{~mm}$. The mold is dried at $50^{\circ} \mathrm{C}$ for 24 hours. After that the film is immersed in $4 \% \mathrm{CaCl} 2$ solution for \pm 10 minutes and dried again in the oven. The formed film is stored and followed by testing the characteristics of the film.

\subsection{Characterization of edible film}

\subsubsection{Thickness of edible film}

The edible thickness test of this film refers to Aleman et al. [7]. The film thickness was measured using a micrometer with a precision of $0.0001 \mathrm{~mm}$. Measurements were made at five different places to get the average thickness representing the sample.

\subsubsection{Tensile strength}

The tensile strength testing process is carried out based on Setiani et al. [8] using Universal Testing Machine. Testing is done by cutting the sample into a paddle shape, then the tip of the sample is clamped by the tensile testing machine. Next, record the thickness and initial length of the sample. The start button on the computer is pressed and the tool will pull the sample at a speed of $100 \mathrm{~mm} /$ minute until the sample breaks. The tensile strength value is 
obtained from the results of the maximum stress distribution with cross-sectional area. The cross-sectional area is obtained from the results of multiplying the initial length of the sample with the initial thickness of the sample. Tensile strength tests were carried out on two samples of edible film which were then averaged.

$$
\begin{aligned}
& \tau=\frac{F \max }{A} \\
& \begin{array}{ll}
\tau \quad=\text { tensile strength }(\mathrm{MPa}) \\
\quad & \mathrm{F}_{\max } \quad=\text { maximum voltage }(\mathrm{N}) \\
\text { A } \quad=\text { cross sectional area }\left(\mathrm{mm}^{2}\right)
\end{array}
\end{aligned}
$$

\subsubsection{Elongation}

Measurement of elongation was carried out based on Setiani et al. [8] in the same way as testing tensile strength. Extension is expressed as a percentage.

Elongation $(\%)=$ breaks length / initial length $\times 100 \%$

\subsubsection{Total soluble matter}

Solubility testing was carried out based on Pereda et al. [9], expressed as a percentage of dry weight of the film dissolved in distilled water for 24 hours. Parts of each sample $(\mathrm{m} 0)$ were weighed with accuracy of $\pm 0,0001 \mathrm{~g}$ and then immersed in $30 \mathrm{ml}$ distilled water for 24 hours. After soaking, the sample was dried at $105 \mathrm{C}$ for 24 hours to measure the weight of the insoluble material (mf).

$$
\operatorname{TSM}(\%)=\frac{m 0-m f}{m 0} \times 100
$$

\subsubsection{Water vapor transmission rate}

The vapor transmission rate of edible film (gram.mm/m2.hari) was measured using the cup method determined gravimetric according to the ASTM E96-01 [10] method. Before being measured, edible film is cut into a circle with a diameter according to the surface diameter of the cup, the thickness of the film is measured using a micrometer, then conditioned in a room with a temperature of $25 \mathrm{C}, \mathrm{RH} 75 \%$ for 24 hours.

\section{Results and discussion}

\subsection{Thickness of edible film}

The thickness of alginate-based edible film is presented in Table 1. Film thickness tended to increase with increasing alginate concentration, this was due to the increasing number of polymers that make up the edible film. The type of packaging that was widely used in foodstuffs usually has a thickness between 0.03-0.06 mm. According to the Japanese industrial standard [11] the film thickness was still relatively good because the maximum value for film thickness is $0.25 \mathrm{~mm}$. The thickness value influenced the mechanical properties 
and the value of the edible film vapor transmission rate. The thicker the edible film, the greater the permeability of water vapor, but the protective effect on food products will be better [12]. However, the thickness of edible film in its function as a food wrapper must be adjusted to the product it packs [13]. According to Fadzilah [14] the length of immersion in $\mathrm{CaCl}_{2}$ gives a real influence on film thickness.

The thickness of edible film is caused by the low interaction between and between alginate molecules, Glycerol, $\mathrm{CaCl}_{2}$ and sunflower oil during the stirring process and drying of edible films. When drying, new hydrophobic interactions and new hydrogen bonds occur. According to Parreidt et al. [15] The thickness of edible film is also caused by alginate sources which affect the ratio of manuronic and guluronic residues. The thickness of edible film at the addition of $2 \%$ alginate concentration was $0.0513 \mathrm{~mm}, 3 \%$ was $0.1215 \mathrm{~mm}, 4 \%$ was $0.117 \mathrm{~mm}, 5 \%$ was $0.135 \mathrm{~mm}$ and $6 \%$ was $0.198 \mathrm{~mm}$. Based on the results of the study the highest thickness value was at $6 \%$ alginate concentration which was worth $0.198 \mathrm{~mm}$. An increase in alginate concentration will cause an increase in the viscosity of the edible film so that the thickness increases. According to Parreidt et al. [15], in general, the thickness of edible film is below $0.3 \mathrm{~mm}$ which can be used in food products to replace or fortify natural layers that can be consumed.

Differences in thickness values, apart from differences in film formulas that affect the dissolved solids content, are also influenced by differences in solution volume, mold area, and drying conditions. The temperature and time used during the drying process will affect the amount of moisture vaporized in the edible film solution. The higher the temperature and the longer the time it is used, the more evaporated water vapor will be, allowing a thinner edible film to be produced. It is very important to control the drying speed carefully and environmental conditions because it will significantly affect the thickness of the final product and the structural characteristics of the product [16].

Table 1. Effect of alginate concentration on characteristic of composite alginate/glicerol/ sunflower oil edible film

\begin{tabular}{|c|c|c|c|c|c|}
\hline Alginate & $\begin{array}{c}\text { Thickness } \\
(\mathrm{mm})\end{array}$ & $\begin{array}{c}\text { Tensile } \\
\text { strength }(\mathrm{MPa})\end{array}$ & $\begin{array}{c}\text { Elongation } \\
(\%)\end{array}$ & $\begin{array}{c}\text { Water } \\
\text { solubility }(\%)\end{array}$ & $\begin{array}{c}\text { WVTR } \\
\left(\mathrm{g} / \mathrm{mm}^{2} / 24 \mathrm{jam}\right)\end{array}$ \\
\hline $2 \%$ & $0.051 \pm 0.003^{\mathrm{c}}$ & $0.249 \pm 0.090^{\mathrm{b}}$ & $28.880 \pm 14.718^{\mathrm{a}}$ & $1.926 \pm 0.016^{\mathrm{a}}$ & $55.781 \pm 3.640^{\mathrm{a}}$ \\
\hline $3 \%$ & $0.122 \pm 0.026^{\mathrm{b}}$ & $2.610 \pm 0.240^{\mathrm{ab}}$ & $48.479 \pm 16.555^{\mathrm{a}}$ & $3.916 \pm 0.675^{\mathrm{ab}}$ & $53.341 \pm 1.151^{\mathrm{a}}$ \\
\hline $4 \%$ & $0.117 \pm 0.004^{\mathrm{ab}}$ & $2.110 \pm 0.380^{\mathrm{a}}$ & $77.260 \pm 20.912^{\mathrm{a}}$ & $5.319 \pm 0.115^{\mathrm{bc}}$ & $50.287 \pm 1.751^{\mathrm{a}}$ \\
\hline $5 \%$ & $0.135 \pm 0.024^{\mathrm{ab}}$ & $0.370 \pm 0.220^{\mathrm{b}}$ & $120.78 \pm 47.595^{\mathrm{a}}$ & $4.286 \pm 1.551^{\mathrm{bc}}$ & $46.934 \pm 4.605^{\mathrm{a}}$ \\
\hline $6 \%$ & $0.198 \pm 0.000^{\mathrm{a}}$ & $1.970 \pm 0.220^{\mathrm{ab}}$ & $124.09 \pm 0.819^{\mathrm{a}}$ & $7.575 \pm 0.227^{\mathrm{c}}$ & $45.418 \pm 8.850^{\mathrm{a}}$ \\
\hline Standard & Max 0.25 & Min 3.92 & Min 10 & & \\
\hline
\end{tabular}




\subsection{Tensile strength}

Tensile strength (TS) is a measure of the strength of edible film specifically, is the maximum pull that can be achieved until the film persists before breaking/breaking [17]. The results of the study (Table 1) showed the highest tensile strength value, namely the concentration of $3 \%$ alginate. This shows that the concentration of $3 \%$ alginate was the best concentration in this study. Variant analysis showed the variance of alginate treatment gave a significant difference $(\mathrm{P}<0.05)$ to the severity of breaking strength. Decreasing TS values is caused by reduced internal hydrogen bonding and the greater decrease in intermolecular forces in polysaccharides. At concentrations of 5\% alginate and $6 \%$ alginate, TS decreases due to edible film results which were fragile in physical appearance.

According to Agusta [18] the tensile strength of edible film alginate with the addition of glycerol and limonene gave a value of 8.7-10.88 MPa. This value was higher due to higher use of alginate. Amaliya [19] reported that edible film used corn starch as a base material, the tensile strength value was 2.5-11 MPa, an increase in tensile strength caused by increasing starch concentration. Ariska [12] stated that the manufacture of edible film with carrageenan as the base material gave tensile strength values of 2.2 to $7.4 \mathrm{Mpa}$.

Table 1 shows that the alginate concentration has a significant effect on the tensile strength. Factors that influence the tensile strength can be caused by the addition of $\mathrm{CaCl}_{2}$. The addition of $\mathrm{CaCl}_{2}$ as a cross-linking agent causes $\mathrm{Ca}^{2+}$ ions to increase the cohesion force, barrier properties, and mechanical strength of alginate edible films [20]. Sabaa et al. [1] reported that the tensile strength was low at a concentration of $1 \%$ due to the influence of castor oil interference with $\mathrm{Ca}^{2+}$ ions responsible for ionic interactions and the formation of cross-linked networks. Futhermore, alginate films have disadvantages, especially, weak mechanical strength because alginate only has a hydroxyl group that is negatively charged; therefore, the bonds between molecules become weak. So this reaction influences mechanical values, such as low tensile strength.

\subsection{Elongation}

The results of the study (Table 1) show the effect of alginate concentration on elongation giving an increasing value of elongation. The highest elongation value was found at $6 \%$ alginate concentration. Alginate is a polysaccharide that has flexible properties. Increasing the alginate concentration will also increase the flexibility / elongation of an edible film. Analysis of variance at the $95 \%$ confidence level showed that the treatment of adding alginate concentration gave a real difference in elongation.

According to Rhim [20], the extension of the alginate film was $14 \%$ and after immersion in $2 \% \mathrm{CaCl}_{2}$ for 5 minutes, the percentage of elongation decreased significantly to $3.4 \%$. In Aziz's study [21] the elongation value of edible alginate was $12 \%$, and continued to increase as the concentration of canola oil was used.

\subsection{Total Soluble Matter}

Solubility is an important physical characteristic of edible film because it is related to the ability of edible film to hold water [22]. The novelty of edible film depends on the product to be applied. Low solubility is desired in High Moisture Food (HMF) products to prevent water migration from products to the environment, as well as to fresh fruit coatings to prevent transpiration. Whereas the high solubility properties are desired in pharmaceutical products or drugs, for example as wrapping capsules or as carriers or vehicles. The effect of alginate concentration on the solubility of edible film is shown in Table 1 . The results of the study (Table 1) showed that the greatest solubility was obtained from a concentration of $6 \%$ 
alginate. Increased solubility is caused by differences in the ratio of the concentration of sunflower oil in each treatment. At $6 \%$ alginate treatment the ratio of sunflower oil tends to be the smallest so that it is more hydrophilic and has a higher solubility. This was also supported by Julianto et al. [23] that the concentration of fatty acids has an effect on the inhibition of the migration of water vapor produced.

Film solubility is used to show film integrity in a liquid environment. Film solubility is a factor that determines the biodegradability of the film when it will be used as packaging. High solubility films show lower water resistance, and show the hydrophilicity of the film. Solubility is influenced by the usage of basic ingredients. This study used hydrophilic alginate base material. Siswanti [24] stated that an increase in the number of hydrophilic components causes an increase in the percentage of film solubility. The increase in solubility is also caused by an increase in polysaccharides in solution [3\}.

\subsection{Water vapor transmission rate}

Table 1 shows that the highest mean water vapor transmission rate was found at $2 \%$ alginate concentration, which was $55.782 \mathrm{~g} / \mathrm{m} 2 / 24$ hours. This value decreased along with the addition of alginate. The lowest value was obtained by edible film with an alginate concentration of $6 \%$, amounting to 45.418. WVTR value decreased at alginate concentration which was increasing due to higher molecular density. High molecular density causes little free space to form in the film matrix, and inhibits water vapor diffusion $[3,25]$.

At $2 \%$ alginate concentration, low WVTR value was caused by the persistence of percent sunflower oil. According to Putranto [26] the concentration of fatty acids affects the inhibitory properties of the water vapor produced. The more fatty acids are added, the greater the hydrophobic nature so that the water vapor transmission rate will decrease further, this is because water vapor migration only occurs in the hydrophilic part, the most effective addition of hydrophobic material to reduce the water vapor transmission rate is $60 \%$.

The results showed that WVTR did not comply with JIS standards. From the analysis results (Table 1) it can be seen that WVTR edible film is influenced by the nature of the material making the edible film [15]. In this study the basic ingredients of alginate were included in the hydrophilic group which retains a little moisture, although sunflower oil has been added to increase its hydrophobicity.

\section{Conclusion}

The alginate concentration significantly affected thickness, tensile strength, elongation and solubility, but did not affect the rate of edible film water vapor transmission made from alginate, glycerol, and sunflower oil. The concentration of $6 \%$ alginate was the best concentration with a thickness of $0.198 \pm 0.000 \mathrm{~mm}$, tensile strength of $1.970 \pm 0.220 \mathrm{MPa}$, elongation of $124.09 \pm 0.819 \%$, solubility of $7.575 \pm 0.227 \%$ and water vapor transmission rate of $45.418 \pm 8.850 \mathrm{~g} / \mathrm{m}^{2} / 24$ hours.

\section{References}

1. M.W. Sabaa, M.S.A. Aziz, H.E. Salama, Food Sci. Technol. 96, 455 (2018)

2. R. Navarro, C. Arancibia, M.L. Herrera, S. Matiacevich, Food Bioprod. Proces. 97, 67 (2016)

3. Warkoyo, B. Rahardjo, D.W. Marseno, J.N.W. Karyadi, Agritech. 34, 107 (2014) 
4. R. Sothomvit, J.M. Krochta, Plasticizers in edible films and coatings, (Academic Press, San Diego, 2005)

5. P.P Utomo, F. Salahudin, Biopropal Indus. 6, 37 (2015)

6. G. Anward, H. Yusuf, R. Nur, J. Teknol. Kimia Indus. 2, 51 (2013)

7. A. Alemán, N. Blanco-Pascual, M.P. Montero, M.C. Gómez-Guillén, Food Hydrocol. 56, 277 (2016)

8. W. Setiani, S. Tety, R. Lena, Jurnal Kimia Valensi 3 (2013)

9. M. Pereda, A. Guillermina, E.M. Norma, Carbohyd. Polym. 87, 1318 (2012)

10. ASTM D-790, Standard test method for flexural properties unrenforcesd and reinforcesd plastic and electrical insulating materials, (American Cociety for Testing and Materials, Philadelpia, 2001)

11. A. Setyaningrum, K.S. Ni, H. Jaya, Nat. Sci.: J. Sci. Technol. 6, 136 (2017)

12. R.E. Ariska, Suyanto, The effect of carrageenan concentration on mechanical and phisical properties of edible film from banana weevil starch and carrageenan with glycerol plastisizer as food pacakaging materials, (Universitas Negeri Surabaya, Surabaya, 2015)

13. D.H. Kusumawati, W.D.R. Putri, J. Pangan Agroind. 1, 90 (2013)

14. A. Fazilah, M. Maizura, A. Abd Karim, K. Bhupinder, B. Rajeev, U. Uthumporn, S.H. Chew, Int. Food Res. J. 18, 1027 (2011)

15. T.S. Parreidt, M. Kajetan, S. Markus, Foods. 7, 170 (2018)

16. E. Tavassoli-Kafrani, H. Shekarchizadeh, M. Masoudpour-Behabadi, Carbohyd. Polym. 137, 360 (2016)

17. J.M. Krochta, C.D. Mulder-Johnston, Food Technol. 51, 61 (1997)

18. K.D. Agusta. Bioplastik Komposit Pati Tapioka Terplastisasi Sorbitol, Natrium alginate, dan Limonena, (B.Sc. Thesis, IPB Bogor, 2014)

19. R.R. Amaliya, W.D.R. Putri, J. Pangan Agroind. 2, 43 (2014)

20. J.W. Rhim, LWT-Food Sci Technol. 37, 323 (2004)

21. M.S. Aziz, M.G. Elsoholy, G.R. Saad, Polym. Composites. 39, E489 (2018)

22. A.I. Bourbon, A.C. Pinheiro, M.A.R. Cerquiera, M.A.C. Quintas, A.A. Vicente, J. Food Eng. 106, 111 (2011)

23. G. Julianto, Ustadi, A. Husni, J. Perikanan. 13, 27 (2011)

24. Siswanti, Karakterisasi edible film komposit dari glukomanan umbi iles-iles (Amorphopallus mulleri Blume) dan maizena. (B.Sc. Thesis, Universits Sebelas Maret Surakarta, 2008)

25. G. Supeni, S. Irawan, J. Kimia Kemasan. 34, 199 (2012)

26. A.T. Putranto, Ekstraksi dan karakterisasi alginat Sargassum sp. dari perairan Gunung Kidul dan pemanfaatanya sebagai biodegradable film. (Master Thesis, Universitas Gadjah Mada Yogyakarta, 2005) 